\title{
Review of Hijacked Justice: Dealing with the Past in the Balkans
}

\author{
MICHAEL D. ROYSTER
}

Division of Social Work, Behavioral and Political Science, Prairie View A\&M University

\section{Hijacked Justice: Dealing with the Past in the Balkans.}

By Julena Subotic (2009): Ithaca, NY \& London, UK: Cornell University Press

This book explores how nations deal with legacies of genocide and ethnic conflict through state noncompliance with international standards based on the phenomenon of "transitional justice," defined by Julena Subotic as the process of collective healing through seeking out the truth. The author argues that this noble cause is often hijacked by the so-called "institutions of transitional justice" which use various forms of coercion (economic, symbolic, and bureaucratic) to force a truncated view of justice onto nations.

According to Subotic, the use of coercion often has the unintended and paradoxical effect of leading justice-seeking countries to respond to external impositions by resisting justice and truth-seeking in various ways. To prove such claims, Subotic examines the cases of three former members of communist Yugoslavia-namely, the republic of Serbia, Croatia, and Bosnia and Herzegovina. Subotic fails to take up the case of the former Yugoslav republic of Slovenia, which achieved independence following a brief two-week long war with Belgrade, and is currently the only former Yugoslav republic to have been admitted into the European Union (EU). The EU is a symbolic promised land, and acts as a pressure point to exact legal and other reforms in former Yugoslav republics. She also omits the cases of Macedonia and Kosovo. War crimes institutions, such as the International Criminal Tribunal for the former Yugoslavia (ICTY) and various other truth commissions have polarized the populations and parties of the three nations in question.

The book sympathizes with the victims due to the author's favourable view of transitional justice functioning as a means towards national healing. However, the author exposes the fallibility of current transitional justice norms and their disturbing yet diverse outcomes as evident in Bosnia, Serbia, and Croatia. Some of these unexpected, negative consequences include the assassination of Serbian reformist 
leader, Zoran Dindic, as well as political paralysis in Bosnia. The author does not offer conclusive resolutions for the welfare of post-conflict societies. Instead, she expresses a call for internal accountability and international involvement because delayed justice which allows perpetrators of war crimes to go unpunished and the abandoning of victims without restitution prevents collective healing and progress.

Subotic concludes by drawing parallels to the cases of Cambodia, Burundi, and Sudan. However, similar tactics of delayed justice prevail in racialized societies such as the United States in terms of racial and ethnic minority groups. Has the United States achieved "transitional justice" and reconciliation with its historical past, including slavery and the extermination of Native Americans? Whenever political leaders can convince the public that the interest of the nation faces imminent danger, efforts at truth telling and reconciliation are abandoned.

The various techniques that legitimize war crimes and delay justice include: (1) turning perpetrators into victims; (2) recourse to various "civil religions" such that national interest comes before the interest of minorities; and, (3) denial of human rights results from challenges to the status quo.

Julena Subotic's book represents a significant contribution to the study of the aftermath of the Balkan War. However, the author fails to explore the reason why some nations seem to be ignored by the international community despite their history with war and genocide - namely, the fact that international propaganda tends to give more attention to those countries which have a significant stake in global markets, neglecting such peripheral nations (as the Balkans) in their post-war and postgenocide years. The problem lies in the premise that war crimes have been presented as "acceptable practices" and are sustained by a code of silence. After carefully analyzing these three case studies the author concludes that "when we deal with the past not as a comprehensive social enterprise but as a mechanistic international requirement, we give political elites who do not think what happened was wrong an opportunity to close accounts on the past instead of opening them" (p. xii). The construction of internal ethical nihilism becomes the price for external national honour with the posture of justice.

Subotic opens the doors for further research and investigation in terms of evaluating the legitimacy of torture techniques, the effectiveness of the use of truth commissions, and operational procedures for governments in transition. The multiple political shifts of the past two decades, the emergence of new satellite nations, and the rearranging of alliances as political powers shift, attest to the relevance for social scientists to further investigate the effectiveness of methods for restructuring postconflict societies. 